\title{
Phytoscreening for vinyl chloride in groundwater discharging to a stream
}

Ottosen, Cecilie Bang; Rønde, Vinni Kampman; Trapp, Stefan; Bjerg, Poul Løgstrup; Broholm, Mette Martina

Published in:

Ground Water Monitoring \& Remediation

Link to article, DOI:

$10.1111 /$ gwmr. 12253

Publication date:

2018

Document Version

Peer reviewed version

Link back to DTU Orbit

Citation (APA):

Ottosen, C. B., Rønde, V. K., Trapp, S., Bjerg, P. L., \& Broholm, M. M. (2018). Phytoscreening for vinyl chloride in groundwater discharging to a stream. Ground Water Monitoring \& Remediation, 38(1), 66-74.

https://doi.org/10.1111/gwmr.12253

\section{General rights}

Copyright and moral rights for the publications made accessible in the public portal are retained by the authors and/or other copyright owners and it is a condition of accessing publications that users recognise and abide by the legal requirements associated with these rights.

- Users may download and print one copy of any publication from the public portal for the purpose of private study or research.

- You may not further distribute the material or use it for any profit-making activity or commercial gain

- You may freely distribute the URL identifying the publication in the public portal 


\title{
Phytoscreening for vinyl chloride in groundwater discharging to a stream
}

\author{
Cecilie B. Ottosen, Vinni Rønde, Stefan Trapp, Poul L. Bjerg and Mette M. \\ Broholm ${ }^{1}$ \\ ${ }^{1}$ Department of Environmental Engineering, Technical University of Denmark, Bygningstorvet, \\ building 115, 2800 Kgs. Lyngby, Denmark.
}

First submitted to Groundwater Monitoring and Remediation, May 2017

This is the revised and accepted version submitted to Groundwater Monitoring and Remediation, November 2017

First published: 11 January 2018 (Early View)

Digital Object Identifier (DOI) - 10.1111/gwmr.12253 


\section{Abstract}

15 This study applies an optimized phytoscreening method to locate a chlorinated ethene plume

16 discharging into a stream. To evaluate the conditions most suitable for successful phytoscreening, trees

17 along the stream bank were monitored through different seasons with different environmental conditions and hence different uptake/loss scenarios. Vinyl chloride (VC) as well as cisdichloroethylene (cis-DCE), trichloroethylene (TCE) and tetrachloroethylene (PCE) were detected in the trees, documenting that phytoscreening is a viable method to locate chlorinated ethene plumes, including VC, discharging to streams. The results reveal, that phytoscreening for VC is more sensitive to environmental conditions affecting transpiration than for the other chlorinated ethenes detected. Conditions leading to higher groundwater uptake by transpiration than contaminant loss by diffusion from the tree trunks are optimal (e.g. low relative humidity, plentiful hours of sunshine and an intermediate air temperature). Additionally, low precipitation prior to the sampling event is beneficial, as uptake of infiltrating precipitation dilutes the concentration in the trees. All chlorinated ethenes were sensitive to dilution by clean precipitation and in some months, this resulted in no detection of contaminants in the trees at all. Under optimal environmental conditions the tree cores allowed detection of chlorinated solvents and their metabolites in the underlying groundwater. Whereas, for less ideal conditions there was a risk of no detection of the more volatile VC. This study is promising for the future applicability of phytoscreening to locate groundwater contamination with the degradation products of chlorinated solvents.

33 Keywords: chlorinated solvents; groundwater; surface water; tree coring 


\section{1. Introduction}

Phytoscreening is a method where samples from trees are used as indicators to characterize subsurface contamination. This method exploits the fact that trees take up contaminated porewater when they transpire, and thereby reflect the underlying pore water chemistry (Burken et al. 2011). The earliest phytoscreening study was conducted in the late 1990's, where headspace analysis of sapwood tree cores was used to delineate groundwater contamination with the chlorinated ethenes TCE and cis-DCE (Vroblesky et al. 1999).

Groundwater contamination with chlorinated ethenes has, in recent studies, shown to be a matter of concern for stream water quality (Rasmussen et al. 2016; McKnight et al. 2012; Weatherill et al. 2014). When groundwater discharges into streams, contaminant plumes appear close to the surface. This is promising for the use of phytoscreening as a rapid and inexpensive method to locate plumes discharging into streams. On the other hand, uptake of the less contaminated water from the stream could dilute the contaminants in the trees to such an extent, that contaminant concentrations are undetectable. Limited studies exist that apply phytoscreening to reflect contaminated groundwater with chlorinated ethenes in the vicinity of a surface water (e.g. Vroblesky et al. 2004).

Phytoscreening has been shown to successfully locate groundwater contamination with chlorinated ethenes (Sorek et al. 2008; Larsen et al., 2008; Limmer et al., 2011); however, these studies have mainly focused on the parent compounds (PCE and TCE) and the degradation products (cis-DCE and VC) have rarely been detected in trees. A need to include VC, the most hazardous of the chlorinated ethenes (Jennings 2011; European Council 1998) remains to be demonstrated. 
54 Phytoscreening studies have shown that concentrations of chlorinated ethenes in trees vary in all three 55 dimensions (Limmer et al. 2013; Vroblesky et al. 2004; Holm and Rotard 2011). Further, seasonal

variation in contaminant concentrations has been observed, where concentrations increased with increasing transpiration (Limmer et al. 2014) and increasing groundwater level (Wittlingerova et al. 2013). Transpiration is positively correlated with environmental conditions such as temperature and hours of sunshine, and negatively correlated with the relative air humidity (Stern 2006). Additionally, an important factor influencing the concentrations in the trees is precipitation, as an uptake of the clean infiltrating precipitation will dilute the concentrations of contaminants in the trees (Vroblesky et al. 2004; Holm and Rotard 2011).

Once taken up in a tree, the chlorinated ethenes behave differently due to their different physicalchemical properties. Diffusional loss of volatile organic compounds from trees is inversely related to their molecular weight (Baduru et al. 2008), and the partitioning coefficient between wood and water is positively correlated to $\mathrm{K}_{\mathrm{ow}}$ (Trapp et al. 2001). The lighter and less hydrophobic degradation products (Cwiertny and Scherer 2010) thus have a shorter residence time within the trees than the parent compounds. The best sampling time for detection of PCE and TCE in trees is after a period with high uptake of contaminated water and low diffusional loss from the tree due to decreased temperatures, resulting in high concentrations in the trees (Wittlingerova et al. 2013). Since cis-DCE and VC have considerable lower residence time in the tree trunk (the half-times of loss from the stem are: PCE = 5.6d, TCE $=6.65 \mathrm{~d}$, cis-DCE $=3.72 \mathrm{~d}$ and VC $=0.25 \mathrm{~d}-$ calculated by the model of Trapp (2007) using the original parameters), their presence in wood is more likely to be dependent on uptake at the time of tree core sampling. 
75 To investigate this hypothesis and add to the knowledge related to phytoscreening for degradation 76 products, the aims of this study were:

$77 \quad$ I. To assess the ability of phytoscreening to detect VC in trees.

II. To evaluate phytoscreening as a method to screen for subsurface groundwater contamination discharging into a stream.

III. To determine the optimal environmental conditions when screening for cis-DCE and, in particular, VC in trees.

82 These aims are addressed by applying an optimized tree core sampling method, compared to the 83 common sampling method, on black alder trees along the bank of a stream influenced by groundwater contaminated with chlorinated ethenes, at different times of the year representing different environmental conditions.

\section{$86 \quad 2$. Study site}

87 The study site is a $250 \mathrm{~m}$ section along the bank of Grindsted stream running through Grindsted town 88 in southern Jutland, Denmark (Figure 1). The stream has a width of 8-12 $\mathrm{m}$ and a depth of 1-2.5 m. The catchment is dominated by sand and sandy clay and is approximately $200 \mathrm{~km}^{2}$. The stream flow ranges 90 from 1151 to $2249 \mathrm{~L} / \mathrm{s}$, and the stream is gaining along this specific section (Rasmussen et al. 2016). A 91 plume of chlorinated ethenes and other contaminants migrates from the former Grindsted factory site, 92 located $1.5 \mathrm{~km}$ north of the stream, towards the stream. PCE, TCE and their degradation products cisDCE and VC have been detected in the surface water (Rasmussen et al. 2016; Sonne et al. 2017; Rønde 94 et al. 2017). The diverse composition of contaminants in the plume enables natural degradation of the chlorinated solvents by reductive dechlorination on its way to the stream. The main components in a 
transect of the groundwater plume near the stream are cis-DCE and VC in concentrations $>5000 \mu \mathrm{g} / \mathrm{L}$ at some locations, while in comparison the PCE and TCE groundwater concentrations were $<200$ $\mu \mathrm{g} / \mathrm{L}$. The contaminant mass discharge to the stream has been shown to be relatively constant with time along this stretch of the stream (Rønde et al. 2017).

For this investigation, six black alder trees (Alnus glutinosa), diameter 0.32-0.48 m, were selected along or nearby the transect of the groundwater plume (Figure 1). Trees of the same species were selected to eliminate variation associated with tree species. Black alder commonly inhabits wet areas (Claessens et al. 2010) and is for that reason believed to be optimal as test tree for screening along streams and rivers. The root system of Alnus glutinosa is unique as it can grow deep into wet and even anaerobic soils (Claessens et al. 2010). However, the main part of tree roots (90\%) can typically be found in the upper $0.6 \mathrm{~m}$ of the soil (Dobson and Moffat 1995). Black alder trees have little control over their stomata mechanism and therefore cannot control transpiration, hence the transpiration is controlled by the weather conditions only (Claessens et al. 2010; Eschenbach and Kappen 1999). 


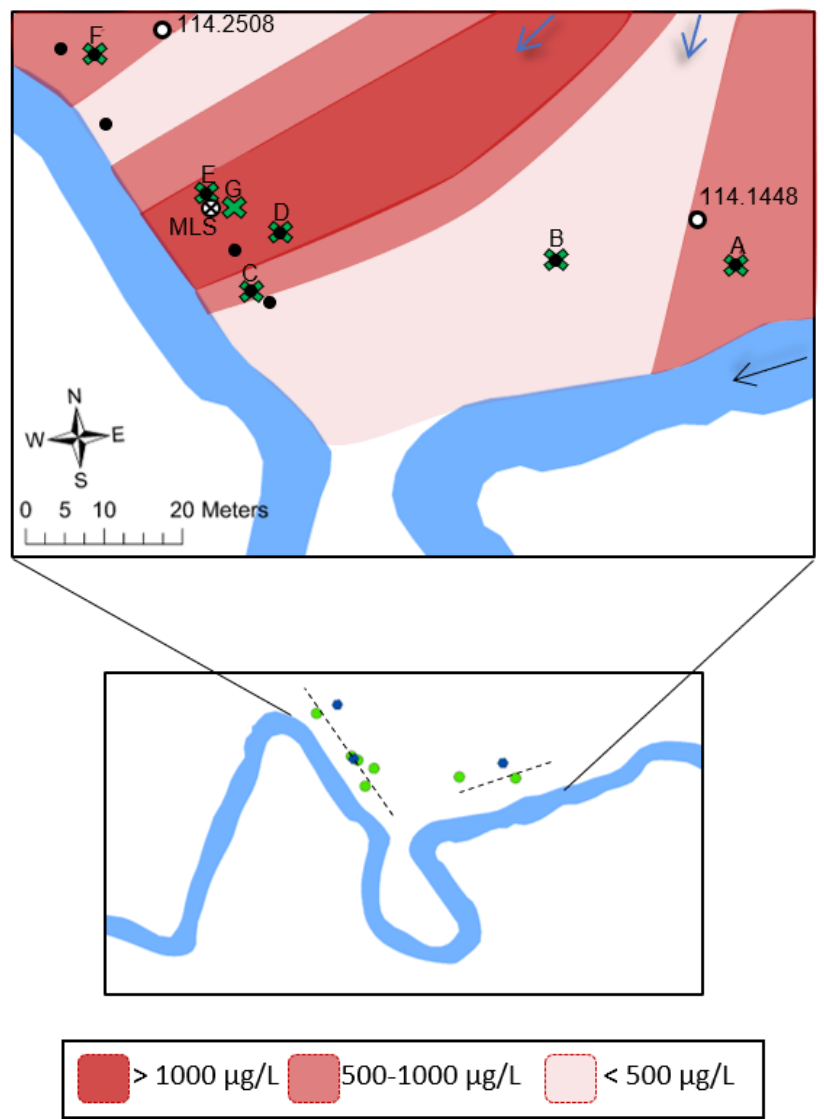

$110 \quad$ Figure 1: Map of the study site at Grindsted stream with the location of the sampling trees (

111 (denoted $A-G)$, the groundwater sampling points $(\bullet)$, the multilevel sampler $(M L S)(\otimes)$, the

112 groundwater level monitoring points (O) (114.2508 and 114.1448) and the stream flow direction (black

113 arrow). A sketch of the contaminant plume of total chlorinated ethenes is illustrated (using

114 measurements from groundwater samplings from the water table to $3 \mathrm{~m}$ below). The approximate flow

115 direction of the plume (shown as blue arrows) is derived from isopotential curves and groundwater

116 flow modeling carried out at the site (Balbarini et al. 2017; Rønde et al. 2017). The dashed lines at the

117 bottom map indicate the location of the cross sections described in the Methods section and Figure 6.

118 The trees, MLS and groundwater monitoring points have been inserted for placement indication.

\section{3. Methods}




\subsection{Tree coring}

121 Tree cores were collected during six campaigns: late February and early May 2015 and in mid-July, 122 mid-August, mid-September and mid-October 2016. The tree cores were collected with an increment borer (Haglöf) approximately one meter above ground level, as explained by Algreen et al. (2015). In subsequent sampling campaigns the samples were collected below the previous sample locations to minimize the impact from the formerly drilled holes. In the last sampling campaign, an additional tree (Tree G), where phytoscreening had not previously been applied, was additionally sampled and compared with Tree E, to confirm or reject whether the holes had a substantial impact on detection of chlorinated ethenes. Four samples were collected around the tree trunk for each tree in every campaign, except in February where only the two sides parallel to the flow direction were sampled. Tree F, which has the largest diameter $(48 \mathrm{~cm})$, was sampled at six points around the stem in May, to investigate the horizontal variation more accurately. In September, it was not possible to collect a tree core at the western side of Tree A, as the cores were stuck in the drilling tool. A total of 24 samples (containing two tree cores each) were collected during most sampling campaigns. Average concentrations for the compounds were calculated for a simpler comparison, and concentrations below the quantification limit were treated as values of zero. Tree cores were collected at two heights in May, to examine if extracting tree cores just above terrain was beneficial for the more volatile degradation products. To optimize the method, with regards to detection of cis-DCE and VC, minor changes were made to the method presented by Algreen et al. (2015):

I. Two tree cores (drilled $\sim 3 \mathrm{~cm}$ from each other) were added to each vial, instead of one. 
loss from the cores during the sampling of the second core, as the tree cores were completely covered by water.

144 III. The samples were incubated for two hours at $80^{\circ} \mathrm{C}$ before analysis to ensure compound transfer from the wood to the headspace. This step compensates for the lower diffusion rate caused by step II.

147 Additionally, each vial was weighed before and after sampling to obtain the concentration per mass of wood. Thereby taking into account the variations in the size of the cores. The information about environmental conditions was collected from the Danish Meteorological Institute.

\subsection{Groundwater measuring points and sampling}

151 The stream and groundwater levels were measured during each sampling campaign to assess: the stability of the groundwater discharge to the stream, and the availability of the groundwater for the tree roots. A thorough investigation of the groundwater contamination by non-permanent drive point piezometers in a transect parallel to the stream was performed by Rønde et al. (2017). The western cross-section in Figure 1 represents the shallow part of this transect. To evaluate the comparison with previous investigations, and to support comparison of phytoscreening results from 2015 and 2016 repeated sampling was performed. A multilevel sampler (MLS) was installed as described by Rügge et al. (1999), next to a previous sampling point. Samples were taken in intervals of $0.25 \mathrm{~m}$ at depths from mbgs. Shallow non-permanent drive point piezometers were further installed close to each tree, except

161 Tree G, at depths between 1.20 - 2.20 mbgs. Two cross-sections were constructed to present data from these locations, as Tree A and B are further upstream than the remaining trees (Figure 1). A peristaltic pump was used for purging and sampling, and samples were filled in $40 \mathrm{ml}$ glass vials with 
164 polypropylene screw cap and silicone/PTFE septum. The samples were preserved with 3 drops of 4M 165 sulfuric acid and stored in a cooler until analysis. Groundwater samples from the piezometers close to 166 the trees were collected in May 2015, and from the MLS in September 2016. Data from selected 167 piezometers installed by Rønde et al. (2017), the piezometers close to the trees and the MLS (the 168 groundwater sampling points) were used to construct an image of total chlorinated ethenes present in 169 the shallow groundwater system (Figure 1). The concentrations in the specific sampling points were 170 depth-averaged over the total depth (from the groundwater table to $3 \mathrm{~m}$ below). Data from the 171 groundwater sampling points were additionally utilized to illustrate the mole fractions in the shallow 172 groundwater (Figure 6).

\subsection{Chemical analysis}

174 The tree cores and groundwater samples were analyzed using a HS-GC-MS (Headspace Gas

175 Chromatography with Mass Spectrometry) as detailed by Algreen et al. (2015). An Agilent 5975C 176 electron impact (70eV) triple-axis mass-selective detector was used for detection and a HP-PLOT/Q 177 capillary column was used for separation. Before analysis, the tree core samples were incubated at $17880^{\circ} \mathrm{C}$ for two hours. Detection limits were $0.25-5.99 \mathrm{ng} / \mathrm{g}$ for PCE, 0.18-1.20 ng/g for TCE, 0.20-1.30 $179 \mathrm{ng} / \mathrm{g}$ for DCE and $0.23-1.51 \mathrm{ng} / \mathrm{g}$ for VC. The detection limit for the separate compounds for each 180 analysis are listed in Table S1.

\section{4. Environmental conditions}

182 The environmental conditions, that are expected to influence the uptake of contaminants by trees are 183 presented in Table 1. Given the residence time of the compounds in the trees, it is assumed that the conditions two weeks prior to the sampling event will influence the measured concentrations. However, 
185 for precipitation it is expected that the influence time is longer, because precipitation is delayed by 186 infiltration before it is taken up by the trees, a period of one month is therefore used for precipitation.

187 The temperature and hours of sunshine were lowest in February and highest in September. The relative 188 humidity was relatively uniform but highest in February and lowest in May. The hours of sunshine and 189 the temperature is assumed to have the biggest influence on the uptake, and the relative humidity is 190 expected less relevant due to the small variation. The months with the highest expected uptake of 191 groundwater, are thus May and September, and the months with lowest expected uptake are February 192 and October.

Table 1: Environmental conditions, from DMI (2016). Conditions determined for a period of two weeks 194 prior to each sampling campaign, however for precipitation data a period of one month was used.

195 Additionally, the measured surface and groundwater level at each campaign is stated as meters above 196 sea level (masl).

\begin{tabular}{|l|c|c|c|c|c|c|}
\hline Campaign & $\begin{array}{c}\text { Feb. } \\
2015\end{array}$ & $\begin{array}{c}\text { May } \\
2015\end{array}$ & $\begin{array}{c}\text { Jul. } \\
2016\end{array}$ & $\begin{array}{c}\text { Aug. } \\
2016\end{array}$ & $\begin{array}{c}\text { Sep. } \\
2016\end{array}$ & $\begin{array}{c}\text { Oct. } \\
2016\end{array}$ \\
\hline $\begin{array}{l}* \text { Average temperature }\left({ }^{\circ} \mathrm{C}\right) \\
(2 \text { weeks) }\end{array}$ & 3.1 & 8.1 & 15 & 15 & 18 & 8.5 \\
\hline $\begin{array}{l}\text { Average relative humidity (\%) } \\
(2 \text { weeks) }\end{array}$ & 91 & 79 & 84 & 82 & 83 & 83 \\
\hline $\begin{array}{l}\text { Sum of sunlight hours } \\
(2 \text { weeks) }\end{array}$ & 16 & 93 & 63 & 68 & 101 & 46 \\
\hline $\begin{array}{l}\text { Sum of precipitation (mm) } \\
(4 \text { weeks) }\end{array}$ & 53 & 41 & 138 & 53 & 58 & 28 \\
\hline $\begin{array}{l}\text { Stream water level } \\
\text { (masl) }\end{array}$ & 34.1 & 33.6 & 33.8 & 33.9 & 33.9 & 33.9 \\
\hline $\begin{array}{l}\text { Groundwater level } \\
(114.1448) \text { (masl) }\end{array}$ & 34.3 & 34.2 & - & 34.8 & 34.8 & 34.7 \\
\hline $\begin{array}{l}* * \text { Groundwater level } \\
(114.2508) \text { (masl) }\end{array}$ & 34.0 & 34.1 & - & 34.2 & 34.2 & 34.1 \\
\hline
\end{tabular}

198 from Billund Airport weather station, $15 \mathrm{~km}$ from the site. The total hours of sunlight and the 
did not exist in 2015 and groundwater levels from nearby points in the transect are given instead. Terrain level is 35.9 masl for 114.1448 and 35.2 masl for 114.2508. Terrain for trees is between 34.0 and 34.8 masl.

The groundwater levels were monitored continuously in two wells (114.1448 and 114.2508, Table 1).

The measurements showed that the groundwater table was generally shallow, with a maximum depth below terrain of approximately $0.6 \mathrm{~m}$ near Tree B in May. It is thus assumed that groundwater was always available for some of the tree roots. Generally, the flow direction was towards the stream as also shown in previous investigations (Rønde et al. 2017; Sonne et al. 2017). Thus, the concentration in the trees is not expected to have been significantly diluted by the uptake of the less contaminated surface water in the stream, and only uptake of infiltrating precipitation is expected to dilute the concentrations.

\section{Results}

\subsection{Chlorinated ethenes concentrations in the groundwater}

Analysis for all chlorinated ethenes were conducted for the groundwater samples from the MLS points. As anticipated the main constituents in the groundwater were cis-DCE and VC. The concentrations of PCE and TCE were $<1 \mu \mathrm{g} / \mathrm{L}$ for all measured depths, which was also observed by Rønde et al. (2017) at comparable locations. The concentration profiles and magnitudes for cis-DCE and VC from the MLS compares well with the results obtained by Rønde et al. (2017) at the corresponding point within the transect, considering the change in the groundwater level (Figure 2). Based on the results from Rønde et al. (2017), the groundwater contaminant mass discharge is approximately constant during the entire period when phytoscreening was conducted. This supports the comparison of phytoscreening results 
221 over the relatively long sampling period. The concentration gradients in the plume transect are very 222 steep vertically (Figure 2) and horizontally (Figure 1) and a slight alteration in the water level and the 223 flow direction of the plume could thereby result in a significant difference in the exposure of the tree 224 roots. Here the results reveal that an increase in groundwater level will increase the exposure of 225 contamination for the roots, as the intensity of roots decrease with increasing depth below ground 226 surface.

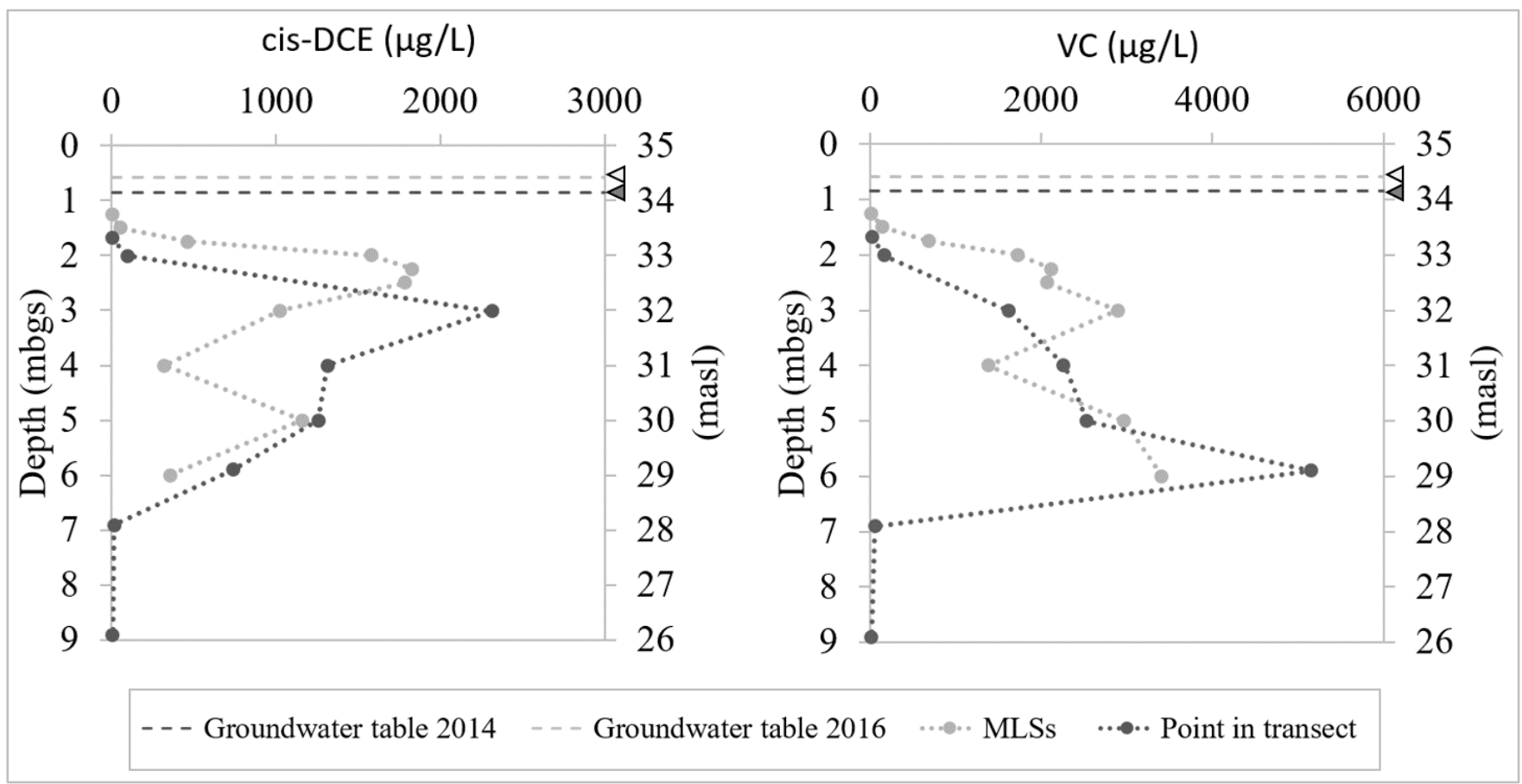

228 Figure 2: Comparison between the concentrations of cis-DCE (left) and VC (right) in the MLS

229 (sampled in fall 2016) and a corresponding point in the transect (depth 1.68-5 m sampled in fall 2014

230 and depth 5.9-8.2 $\mathrm{m}$ sampled in spring 2015). Note the different $x$-axis for the two compounds. The

231 groundwater table data are derived from well 114.1448.

\subsection{Contaminants in the tree cores}


233 The horizontal variation of contaminant concentration in the trees is assessed by comparing the

234 measurements around the tree trunk. No correlation was found between the inflow direction and the

235 horizontal variation in the stem. The concentrations of cis-DCE and VC measured in trees are

236 illustrated in Figure 3. PCE and TCE were detected to a lesser extent both temporally and spatially

237 (Figure S1). The quantity of drilled holes in the tree stem does not appear to have had a significant

238 influence on detection of chlorinated ethenes in the trees, as Tree G (only sampled in October) and Tree

239 E (sampled in all campaigns), which are located a few meters from each other, had similar

240 concentration levels (see Figure S1 for concentration variation in Tree G). Additionally, the increase of

241 concentrations in the last sampling events indicates that the previously drilled holes had not

242 significantly affected the flow at the location of the new hole. Hence, the results are considered valid

243 for comparison.

a) cis-DCE

Tree B

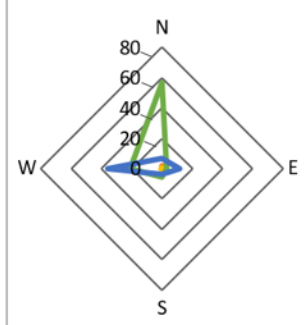

Tree D

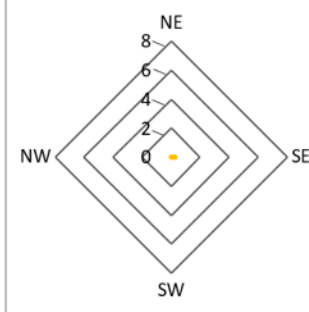

244

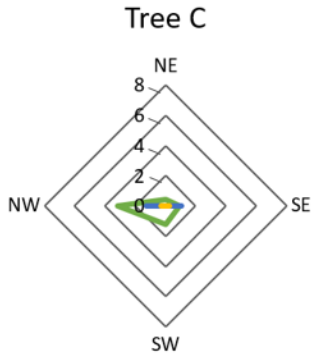

b) VC
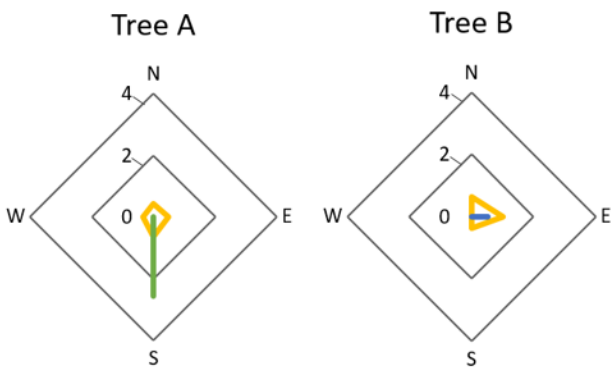

Tree D

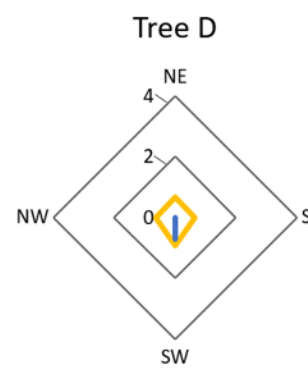

Tree E
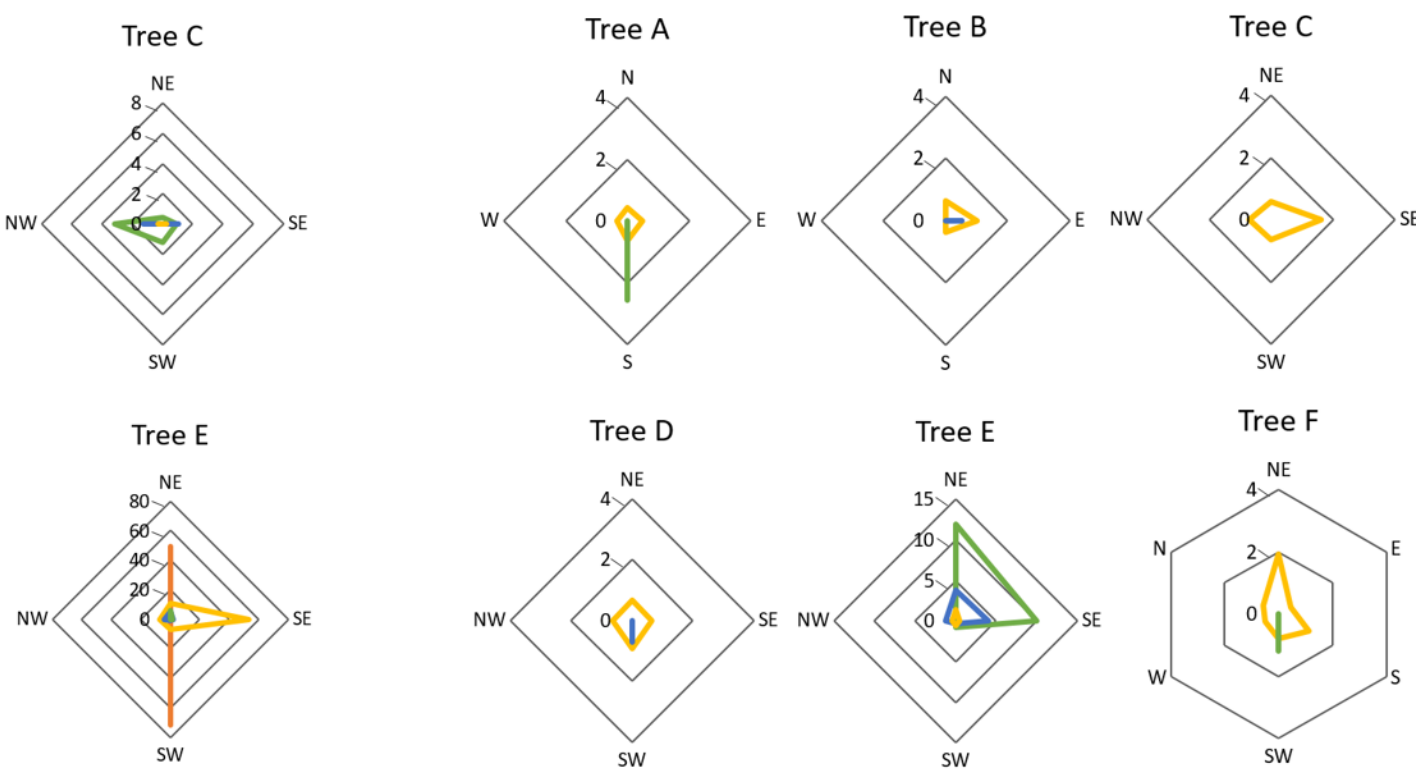

Tree F

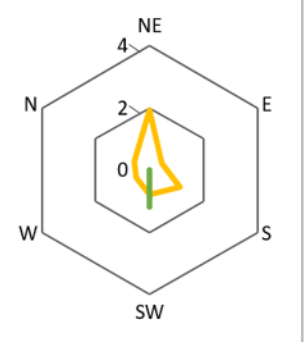


246 Figure 3: cis-DCE (a) and VC (b) concentrations (ng/g) around the stem from each sampling event

247 illustrating the horizontal variation at each tree. Note different scales. For months or trees not

248 included the concentrations were below the quantification limit or not detected (except Tree G, see

249 Figure S1). No contaminants were found in the trees in July and August. The stream is located south

250 (S) of Tree A and B, and southwest (SW) of Tree C-F, see Figure 1.

251 The highest concentration of VC was found to be 11.9 ng/g in Tree E in September. VC was detected

252 in all trees in May, where the highest concentration, out of all sampling months, was also found for

253 most trees (0.91-1.93 ng/g for Tree B, C, D and F). cis-DCE was detected in most sampling trees (Tree

254 B, C, D, E, G) with the highest concentration of $71.8 \mathrm{ng} / \mathrm{g}$ in Tree E in February and the second highest

255 of $56.6 \mathrm{ng} / \mathrm{g}$ in Tree B in September. TCE was found only in October in Tree B with a highest

256 concentration of $6.50 \mathrm{ng} / \mathrm{g}$. PCE was detected in two of the trees, B and F, with the highest

257 concentration of $31.0 \mathrm{ng} / \mathrm{g}$ in October and $1.29 \mathrm{ng} / \mathrm{g}$ in May, respectively. No chlorinated ethenes were

258 detected in the trees in July and August 2016. The results demonstrate that the horizontal concentration

259 in the trees varies for VC and cis-DCE, as have been observed for the other chlorinated ethenes in

260 previous studies (Limmer et al. 2013; Holm and Rotard 2011). The variation, expressed as standard

261 deviation, around the stem for an individual compound is high, clarifying the importance of sampling

262 several points around the stem in each sampling event.

263 No clear trends were observed in VC concentrations over height (Figure 4), contrary to what have

264 previously been observed for the parent compound TCE (Vroblesky et al. 2004; Vroblesky et al. 1999).

265 The average concentration of VC decreased $18 \%$ with height in Tree B and increased $19 \%$ in Tree C,

266 demonstrating that diffusional loss out of the stem is not the only important factor for concentrations of

267 VC at different heights. The average concentrations increased with height in both trees for cis-DCE, 
268 but based on fewer points of detection (Figure S2). As no clear advantage of sampling for VC near 269 terrain was observed, the tree cores were only sampled at the usual and more convenient height of one

270 meter above terrain in the subsequent sampling events. Nevertheless, sampling near terrain could be

271 beneficial in areas with higher ambient temperatures than Denmark and thus with more dominating

272 diffusional losses.

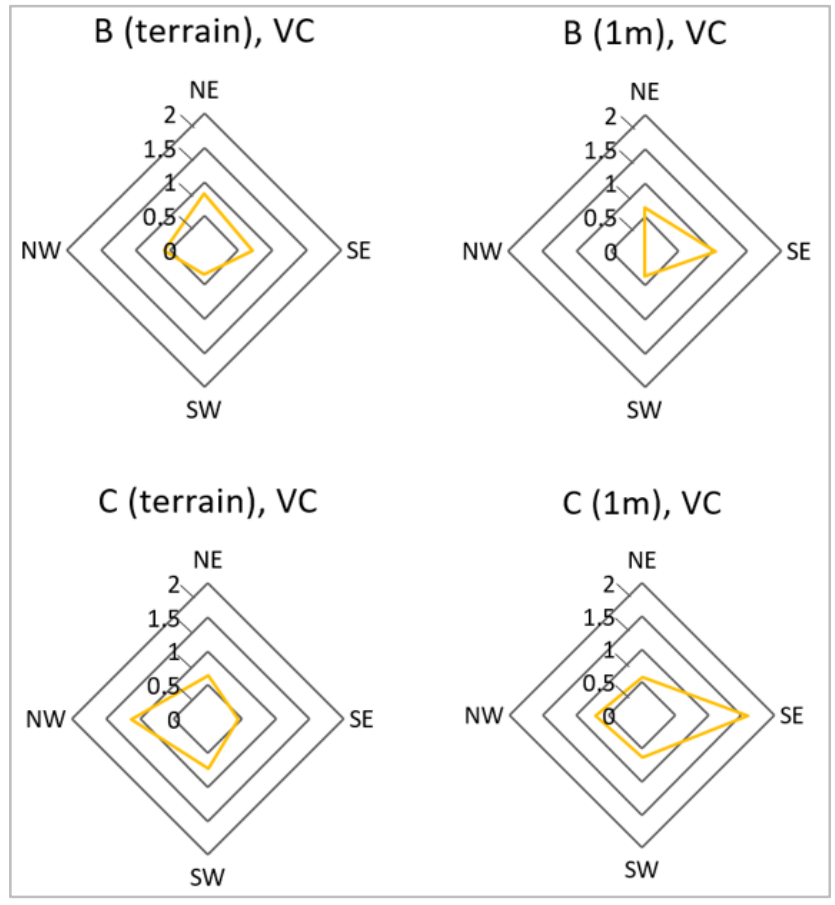

274 Figure 4: The concentration of VC (ng/g) in tree B and C around the stem at two heights (terrain and 275 one meter above terrain), measured in May 2015.

\section{6. Discussion}

\section{$277 \quad 6.1$ Influence of environmental factors on uptake of chlorinated ethenes into trees}


278 To investigate trends in detection of chlorinated ethenes in the trees over time, average concentrations

279 were calculated for each individual contaminant, see Table S1. The temporal average concentrations 280 are illustrated in Figure 5. 

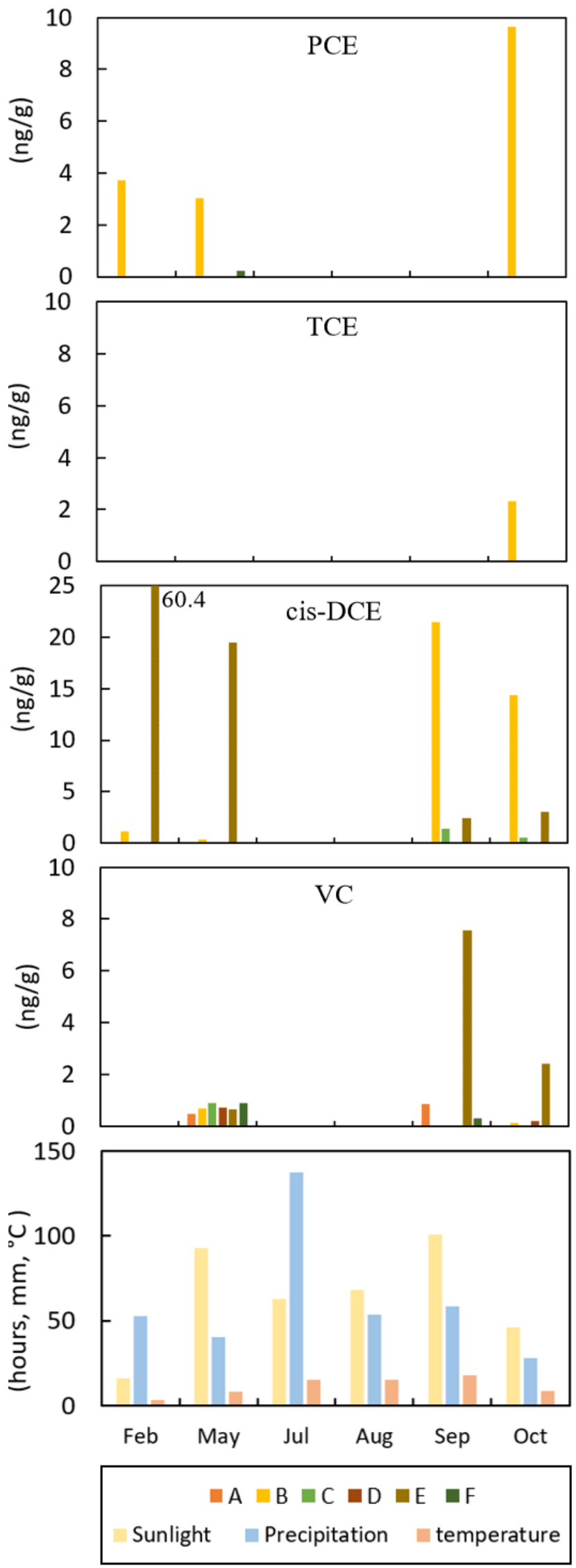
Figure 5: Average concentrations of the chlorinated ethenes in trees and environmental conditions for

283 each sampling month. The weather data is from Table 1. Unit for sunlight is hours, for precipitation is $m m$, and for temperature is ${ }^{\circ} \mathrm{C}$. Tree $G$ is not included as it was only sampled in October. Note the different $y$-axis for cis-DCE.

The results indicate, as expected, that the presence of VC in the trees is more sensitive to the transpiration than cis-DCE and PCE. This is illustrated by the absence of VC in the trees in February where the transpiration was low, in contrary VC was detected in all trees in May, while cis-DCE and PCE were detected in trees in both months. When the transpiration is minimal only contaminants retarded in the trees by sorption are likely to be seen, and less retarded and lighter compounds have been lost by diffusion out of the stem (Banduru et al. 2008). The indication that detection of VC is only possible when the uptake is high, is consistent with the fact that VC has a lower sorption to wood than the other chlorinated ethenes (Trapp et al. 2001). Despite the significantly lower groundwater concentrations for PCE and TCE, the magnitudes in the trees were the same as for cis-DCE and VC in low transpiration periods, consistent with their higher adsorption to wood.

The inter-annual trends can be explained by two scenarios: A) where the uptake (dependent on temperature, relative humidity, sunshine hours and precipitation) by the tree is larger than the loss (dependent on temperature and physical-chemical properties of the compounds), and B) where the uptake by the tree is smaller than the loss. Since VC has a short lifetime (due to volatile loss) in trees, it is only found in Scenario A. Therefore, Scenario B must have been present in February, July and August. In February, it was simply a matter of minimal uptake due to limited transpiration. In July and August, the loss out of the stem must have been significantly higher than the uptake, in contrast to in May and September. Which could primarily be explained by the smaller amount of sunshine hours, the 
availability of water in the unsaturated zone originating from infiltrating precipitation, and an increased diffusion out of the stem due to the relatively high temperatures. Scenario A was present in May, September and October. The small amount of precipitation in October was beneficial for uptake of groundwater into trees, and the lower temperature resulted in decreased diffusion out of the stem. VC was found in all trees in May and likely is a result of the requirement of large amounts of water due to long sunshine hours, which is also the case for September. In areas or at times where porewater is limited, trees take up water from below the groundwater table and translocate it to the unsaturated zone by night (Lubczynski 2009) and thereby they may relocate the groundwater contamination. The groundwater table was lowest in May, and translocation of the groundwater could thus explain the lower but more evenly distributed VC concentrations observed (VC being the most volatile and mobile of the chlorinated ethenes). Additionally, in May the low relative air humidity and the lower temperature were beneficial for transpiration and decreased the diffusional loss, respectively. The detection of PCE and cis-DCE in the trees in February, where transpiration is negligible, must have been due to uptake in preceding months and their longer lifetime in the trees than VC.

The inter-annual variation in the detection of chlorinated ethenes in trees illustrates some important patterns that the influence the environmental conditions have on the uptake. First, Limmer et al. (2014) found a correlation between the transpiration and tree concentrations, however in this study we illustrate that the uptake of groundwater contamination is not the only parameter influencing the detection in the trees. We found that also the loss out of the stem and the precipitation is of high importance, explaining the lack of contaminant detection in the summer months with a relatively high temperature and wet weather. When the loss out of the stem was larger than the uptake, VC was not detected in the trees, and the best time to screen for VC is therefore while the uptake is high. Whereas 
326 detection of cis-DCE was not as sensitive documented by the detection in February. Second, rainfall

327 will decrease concentrations in trees, which has previously been documented for some of the

328 chlorinated ethenes (Vroblesky et al. 2004; Holm and Rotard 2011), and here we also show the same

329 for VC by the lack of detection (especially July). Even the lack of detection in August could be due to

330 remaining water in the top soil from July's weather events. It is therefore recommended that screening

331 for all chlorinated ethenes be conducted during dry periods with many sunshine hours and not after

332 intense and/or prolonged rainfall. Third, that VC appears most sensitive to spreading in the unsaturated

333 zone by diffusion in pore air when trees relocate groundwater during dry periods, causing a more

334 evenly distributed contaminant concentration. This spreading is important to consider when using

335 phytoscreening to delineate VC groundwater plumes. If the uptake by the trees is high enough the

336 plume will appear broader than it is, in contrast there is a risk of no contaminant detection as the

337 spreading will result in lower water concentrations.

\section{$338 \quad 6.2$ Comparison of contamination in groundwater and trees}

339 The uptake of water by trees is gradient driven. The water-potential gradient between the groundwater 340 table and the dry air above the ground surface is very steep (Larcher 1995), therefore, trees take up the

341 water available closest to the surface (i.e. in the vadose zone or shallow groundwater zone).

342 Consequently, shallow groundwater is most relevant for comparison with trees. The shallow

343 groundwater composition in mole fractions is compared to the composition in the trees in May in

344 Figure 6, and the compositions in the trees in the remaining months are presented in Table 2. May was

345 selected for comparison to represent a month with favorable environmental conditions for uptake.

346 These results demonstrate that when the uptake was low (February and October) the lower lifetime in

347 the trees for VC was reflected in lower or no detection compared to months with higher uptake (i.e. 
348 Tree A and F). This confirms the greater sensitivity of VC tree coring to factors affecting transpiration.

349 Generally, it can be concluded that the groundwater measurement points were not shallow enough to 350 allow a correlation between groundwater and tree core data. However, the results reveal that under 351 favorable conditions the tree coring method is usefil as a screening tool to provide a depiction of the 352 underlying groundwater contaminants, including the degradation products. Phytoscreening can thus be 353 used to locate, but not quantify, shallow groundwater contaminated with cis-DCE and VC discharging 354 into a stream. However, this is only the case when the uptake by the trees is higher than the loss and 355 given that no intense and/or prolonged rainfall events occur prior to the sampling. Dilution by the 356 cleaner stream water did not appear to influence the detection of the chlorinated ethenes in the trees, 357 even for those trees standing close to the bank (within few meters). Detection of underlying 358 groundwater contaminants in trees has been documented before for the parent compounds and cis-DCE 359 (Sorek et al. 2008; Larsen et al. 2008; Limmer et al. 2011); however, our results emphasize that 360 detection can also be obtained for the degradation product VC under favorable uptake conditions. 

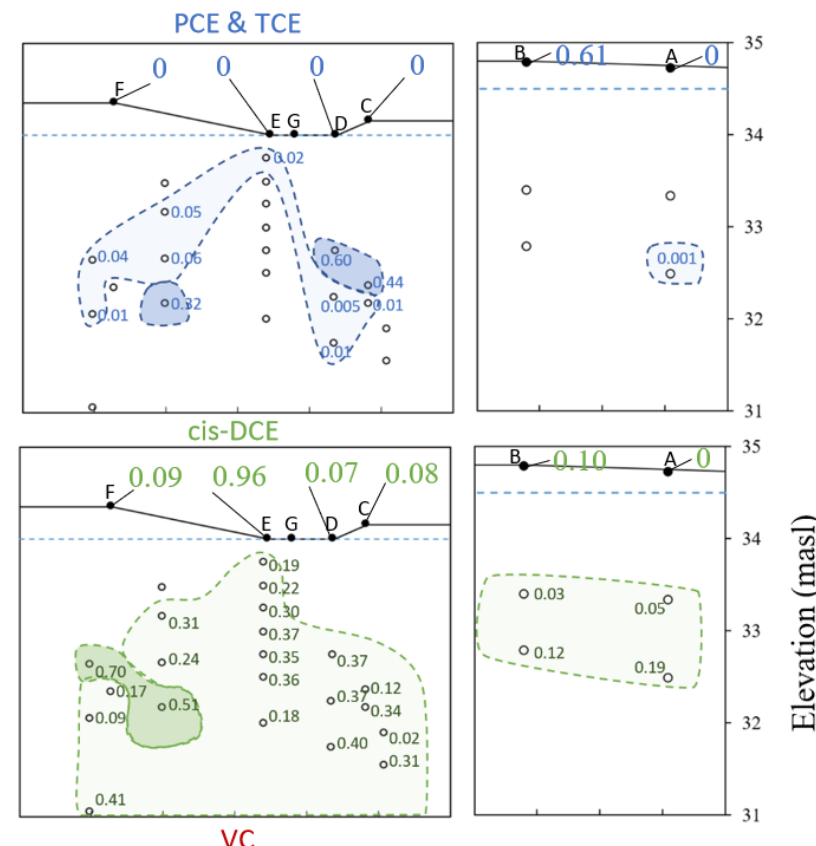

361
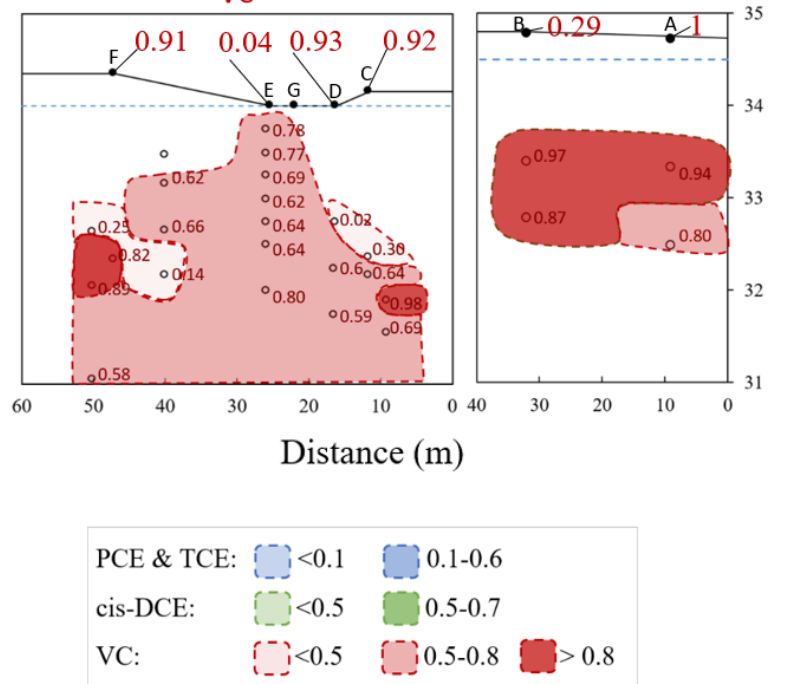

362 Figure 6: Mole fractions in the groundwater and in the trees (in May where the transpiration was

363 high). The trees are projected into the cross sections shown in Figure 1. Points in white areas indicate

364 that the contaminant was not detected or that the concentration was below detection limit.

365 Table 2: Mole fractions of chlorinated ethenes in the trees. July and August measurements are not

366 included as no contaminants were detected in the trees. The color coding is the same as in Figure 6. 


\begin{tabular}{|c|c|c|c|c|c|c|c|c|}
\hline & & Tree A & Tree B & Tree C & Tree D & Tree $\mathrm{E}$ & Tree F & Tree G \\
\hline Feb. & $\begin{array}{l}\text { PCE } \\
\text { cis-DCE } \\
\text { VC }\end{array}$ & N.D. & $\begin{array}{l}0.65 \\
0.35 \\
\text { N.D. }\end{array}$ & N.D. & N.D. & $\begin{array}{c}\text { N.D. } \\
1 \\
\text { N.D. }\end{array}$ & N.D. & N.M. \\
\hline May & $\begin{array}{l}\text { PCE } \\
\text { cis-DCE } \\
\text { VC }\end{array}$ & $\begin{array}{l}0 \\
0 \\
1\end{array}$ & $\begin{array}{l}0.61 \\
0.10 \\
0.29\end{array}$ & $\begin{array}{c}0 \\
0.08 \\
0.92\end{array}$ & $\begin{array}{c}0 \\
0.07 \\
0.93\end{array}$ & $\begin{array}{c}0 \\
0.96 \\
0.04\end{array}$ & $\begin{array}{c}0.09 \\
0 \\
0.91\end{array}$ & N.M. \\
\hline Sep. & $\begin{array}{l}\text { PCE } \\
\text { cis-DCE } \\
\text { VC }\end{array}$ & $\begin{array}{l}0 \\
0 \\
1 \\
\end{array}$ & $\begin{array}{l}0 \\
1 \\
0 \\
\end{array}$ & $\begin{array}{l}0 \\
1 \\
0 \\
\end{array}$ & $<Q L$ & $\begin{array}{c}0 \\
0.17 \\
0.83 \\
\end{array}$ & $\begin{array}{l}0 \\
0 \\
1 \\
\end{array}$ & N.M. \\
\hline Oct. & $\begin{array}{l}\text { PCE } \\
\text { cis-DCE } \\
\text { VC }\end{array}$ & $<Q L$ & $\begin{array}{c}0.35^{*} \\
0.64 \\
0.01\end{array}$ & $\begin{array}{l}0 \\
1 \\
0\end{array}$ & $\begin{array}{l}0 \\
0 \\
1\end{array}$ & $\begin{array}{c}0 \\
0.44 \\
0.56\end{array}$ & $<Q L$ & $\begin{array}{c}0 \\
0.55 \\
0.45\end{array}$ \\
\hline
\end{tabular}

* includes both PCE and TCE as it was the only point where TCE was also detected.

\section{Conclusion}

Phytoscreening for chlorinated ethenes along the bank of Grindsted stream (Denmark) strongly impacted by groundwater contamination revealed maximum concentrations in black alder trees of 31.0 ng/g for PCE, $6.50 \mathrm{ng} / \mathrm{g}$ for TCE, $71.8 \mathrm{ng} / \mathrm{g}$ for cis-DCE and $11.9 \mathrm{ng} / \mathrm{g}$ for VC. Composition of environmental factors influencing transpiration (temperature, relative humidity and hours of sunshine) proved to be crucial for detection of vinyl chloride in the trees. VC, having the shortest lifetime in the trees (due to diffusional loss), was only detected in periods with low precipitation and many sunshine hours. Hence, to detect VC in trees it is required that the trees transpire VC contaminated groundwater at the time sampled. High precipitation resulted in dilution of in-tree concentrations. Therefore, it is

377 recommended to avoid screening for any of the compounds after the occurrence of intense and/or prolonged rainfall events. The favorable environmental conditions prior to and during sampling, to reflect all of the chlorinated ethenes, are thus: low relative air humidity, low amount of precipitation/dry vadose zone soils, moderate temperatures and plentiful hours of sunshine. Under these conditions the trees uptake of contaminants is assessed higher relative to the diffusive loss. This study 
382 demonstrates that phytoscreening can be used to detect shallow groundwater contamination with

383 chlorinated ethenes, including cis-DCE and VC, in the vicinity of a stream under optimal

384 environmental conditions.

385 


\section{Acknowledgements}

387 Field sampling and analysis of groundwater samples was supported by the GEOCON project

“Advancing GEOlogical, geophysical and CONtaminant monitoring technologies for contaminated site investigation”, which was funded by The Innovation Fund Denmark.

\section{References}

391

392

393

394

395

396

397

398

399

400

401

402

403

404

405

406

407

408

409

410

411

412

413

414

415

416
Algreen M., Trapp, S., Jensen, P. R. and Broholm M. M., 2015, “Tree coring as a complement to soil gas screening to locate PCE and TCE source zones and hot spots”, Groundwater Monitoring and Remediation 35, 57-66.

Baduru, K. K., Trapp, S. and Burken J. G., 2008, “Direct Measurement of VOC diffusivities in Tree Tissues: Impacts on Tree-Based Phytoremediation and Plant Contamination”, Environmental Science and Technology 42, 1268-1275.

Balbarini, N., Boon, W. M., Nicolajsen, E., Nordbotten J. M., Bjerg, P. L. and Binning, P. J., 2017, ”A 3-D numerical model of the influence of meanders on groundwater discharge to a gaining stream in an unconfined sandy aquifer”, Journal of Hydrology 552, 168-181.

Burken J. G., Vroblesky D. A. and Balouet J. C., 2011, "Phytoforensics, Dendrochemistry, and Phytoscreening: New Green Tools for Delineating Contaminants from Past and Present”, Environmental Science and Technology 45, 6218-6226.

Claessens H., Oosterbaan A., Savill P and Rondeux J., 2010, “A review of the characteristics of black alder (Alnus glutinosa (L.) Gaertn.) and their implications for silvicultural practices”, Forestry 83, 163175.

Cwiertny, D. M. and Scherer M. M., 2010, “Chlorinated Solvent Chemistry: Structures, Nomenclature and Properties” in In Situ Remediation of Chlorinated Solvent Plumes, 29-37, Springer.

DMI (Danish Meteorological Institute), 2016, “Archives” and "Weekly overview” [in Danish], assessed December 2016, http://www.dmi.dk/vejr/arkiver.

Dobson M. C. and Moffat A. J., 1995, “A re-evaluation of objections to tree planting on containment landfills”, Waste Management and Research 13, 579-600.

European Council, 1998, “Council Directive 98/83/EC of November 1998 - on the quality of water intended for human consumption”, Council Directive 98/83/EC

Holm O. and Rotard W., 2011, "Effect of Radial Directional Dependences and Rainwater Influence on CVOC Concentrations in Tree Core and Birch Sap Samples Taken for Phytoscreening Using HSSPME-GC/MS”, Environmental Science and Technology 45, 9604-9610. 
417 Jennings A. A., 2011, "Worldwide Residential Soil Regulatory Guidance Values for Chlorinated

418 Ethenes”, Journal of Environmental Engineering - ASCE 137, 651-668.

419 Larcher, W., 1995, Physiological Plant Ecology, Berlin: Springer.

420 Larsen M., Burken J., Machackova J., Karlson U. G. and Trapp S., 2008, “Using Tree Core Samples to 421 Monitor Natural Attenuation and Plume Distribution After a PCE Spill”, Environmental Science and 422 Technology 42, 1711-1717.

423 Limmer M. A., Balouet J. C., Krag F., Vroblesky D. A. and Burken J. G., 2011, "Phytoscreening for 424 Chlorinated Solvents Using Rapid in Vitro SPME Sampling: Application to Urban Plume in Verl, 425 Germany”, Environmental Science and Technology 45, 8276-8282.

426 Limmer M. A., Shetty M. K., Markus S., Kroeker R., Parker B. L., Martinez C. and Burken J. G., 2013, 427 "Directional Phytoscreening: Contaminant Gradients in Trees for Plume Delineation”, Environmental 428 Science and Technology 47, 9069-9076.

429 Limmer M. A., Holmes A. J. and Burken J. G., 2014, "Phytomonitoring of Chlorinated Ethenes in 430 Trees: A Four-Year Study of Seasonal Chemodynamics in Planta”, Environmental Science and 431 Technology 48, 10634-10640.

432 Lubczynski, M. W., 2009, “The hydrogeological role of trees in water-limited environments”, 433 Hydrogeology Journal 17, 247-259.

434

435

436

437

438

439

440

441

442

443

444

445

446

447

448

449

450

451

452

453
McKnight, U. S., Rasmussen, J. J., Kronvang, B., Bjerg, P. L. and Binning P. J. (2012). “Integrated assessment of the impact of chemical stressors on surface water ecosystems". Science of the Total Environment 427-428, 319-331.

Rasmussen J. J., McKnight U. S., Sonne A. T., Wiberg-Larsen P. and Bjerg P. L., 2016, “Legacy of a Chemical Factory Site: Contaminated Groundwater Impacts Stream Macroinvertebrates”, Archives of Environmental Contamination and Toxicology 70, 219-230.

Rügge, K., Bjerg, P. L., Pedersen, J. K., Mosbæk, H. and Christensen T. H., 1999, “An anaerobic field injection experiment in a landfill leachate plume, Grindsted, Denmark 1. Experimental setup, tracer movement, and fate of aromatic and chlorinated compounds”, Water Resources Research 35, 12311246.

Rønde V. K., McKnight U. S., Sonne A. T., Devlin J. F. and Bjerg P. L., 2017, “Contaminant mass discharge to streams: Comparing direct groundwater velocity measurements and multi-level groundwater sampling with an in-stream approach”, Journal of Contaminant Hydrology 206, 43-54.

Sonne, A. Th., McKnight, U. S., Rønde, V. and Bjerg, P. L., 2017, “Assessing the chemical contamination dynamics in a mixed land use stream system”, Water Research 125, 141-151.

Sorek A., Atzmon N., Dahan O., Gerstl Z., Kushisin L., Laor Y., Mingelgrin U., Nasser A., Ronen D., Tsechansky L., Weisbrod N. and Graber E. R., 2008, “"Phytoscreening”: The Use of Trees for Discovering Subsurface Contamination by VOCs”, Environmental Science \& Technology 42, 536-542.

Stern, K. R., 2006, “Water in Plants” In Introductory Plant Biology, 149-164, Boston: McGraw-Hill Higher Education. 
454 Trapp S., Miglioranza, K. S. B. and Mosbæk H., 2001, "Sorption of Lipophilic Organic Compounds to 455 Wood and Implications for Their Environmenral Fate”, Environmental Science and Technology 35, 456 1561-1566.

457 Trapp, S., 2007, “Fruit tree model for uptake of organic compounds from soil and air”, Sar - Qsar in 458 Environmental Research 18, 367-387.

459 Vroblesky D. A., Nietch C. T. and Morris J. T., 1999, "Chlorinated Ethenes from Groundwater in Tree 460 Trunks”, Environmental Science and Technology 33, 510-515.

461 Vroblesky D. A., Clinton B. D., Vose J. M., Casey C. C., Harvey G. J. and Bradley P. M., 2004, 462 "Ground Water Chlorinated Ethenes in Tree Trunks: Case Studies, Influence of Recharge, and 463 Potential Degradation Mechanisms”, Ground Water Monitoring and Remediation 24, 124-138.

464 Weatherill, J., Krause, S., Voyce, K., Drijfhout, F., Levy, A. and Cassidy, N., 2014, “Nested 465 monitoring approaches to delineate groundwater trichloroethene discharge to a UK lowland stream at 466 multiple spatial scales”, Journal of Contaminant Hydrology 158, 38-54.

467 Wittlingerova Z., Machackova J., Petruzelkova A., Trapp S., Vlk K. and Zima J., 2013, “One-year 468 measurements of chloroethenes in tree cores and groundwater at the SAP Mimoň Site, Northern 469 Bohemia”, Environmental Science and Pollution Research 20, 834-847. 